REVISTA DE CONTABILIDAD

SPANISH ACCOUNTING REVIEW

\title{
Key mechanisms of the accountability process in public-private partner- ships
}

\author{
Jose Antonio Reyes-González ${ }^{a}$, Marc Esteve ${ }^{\mathrm{b}}$ \\ a) Candidate from University College London, Department of Political Science. The Rubin Building, Tavistock Square, London. \\ b) Senior Lecturer in International Public Management - MPA Programme Director at University College London, Department of Political Science. The Rubin Building, \\ Tavistock Square, London.
}

${ }^{a}$ Corresponding author.

E-mail address: antonio.reyes.16@ucl.ac.uk

\section{A R T I C L E I N F O}

Article history:

Received 22 March 2019

Accepted 6 July 2019

Available online 1 July 2020

\section{JEL classification:}

D73

J18

L33

Keywords:

Literature review

Public-Private Partnership

Accountability

Behaviour

Information

Evaluation

Sanction

\section{A B S T R A C T}

This article brings together empirical academic research on accountability in Public-Private Partnerships (PPPs). Via a systematic literature review, we explored how well grounded are concerns about PPPs eroding accountability. We investigated over 50 publications on PPPs, published between 1983 and 2017. These studies were analysed in lights of a categorisation framework of publications to map out the process through which accountability takes place in practice for PPPs. Four key accountability mechanisms stand out in our analysis: behaviour, information, evaluation and sanction. Based upon this analysis, we identified four main account-holders and the mechanisms they employ to participate in the overall accountability process of PPPs. Since none of them can exert full control over the mechanisms of accountability available to them, we argue that this unbalanced and chaotic state of contradicting and overlapping demands of accountability indeed generates accountability deficits, but it can be turned into an advantage if interdependency and complementarity between account-holders is further validated.

(C)2020 ASEPUC. Published by EDITUM - Universidad de Murcia. This is an open access article under the CC BY-NC-ND license (http://creativecommons.org/licenses/by-nc-nd/4.0/).

Mecanismos clave del proceso de rendición de cuentas en las asociaciones público-privadas

RES U MEN

Este estudio analiza el cuerpo de la investigación académica y empírica disponible respecto a las Asociaciones Público-Privadas (APPs). A través de una revisión sistemática de la literatura, exploramos qué tan justificadas son las preocupaciones sobre las APPs erosionando los procesos de rendición de cuentas a los que debieran estar sujetas. Para ello, investigamos más de 50 estudios de APPs publicados entre 1983 y 2017. Estos estudios fueron analizados a través de un marco de categorización que permitió mapear el proceso por el cual la rendición de cuentas de APPs toma lugar en la práctica. Cuatro mecanismos claves sobresalen en este proceso: comportamiento del agente, información sobre el comportamiento, evaluación de información y sanción del comportamiento. Basados en estos mecanismos pudimos identificar, además, cuatro figuras principales con derecho legítimo a solicitar información a las APPs y los mecanismos que utilizan para participar en este proceso general de transparencia y rendición de cuentas. Dado que ninguno de estas figuras principales ejerce control total sobre los cuatro mecanismos clave, argumentamos que esto configura un estado caótico de demandas traslapadas y contradictorias para las APPs. Una falta de coordinación que conlleva, en efecto, a un déficit en la rendición de cuentas. Sin embargo, proponemos que este estado disímbolo de las cosas puede convertirse en una ventaja única en caso de validarse la interdependencia y complementariedad entre las demandas de los principales.

(C)2020 ASEPUC. Publicado por EDITUM - Universidad de Murcia. Este es un artículo Open Access bajo la licencia CC BY-NC-ND (http://creativecommons.org/licenses/by-nc-nd/4.0/) 


\section{Introduction}

Public-Private Partnerships (PPPs) have been gaining increasing attention around the world. Proponents have reinforced favourable publicity for these procurement models to provide public goods in terms of infrastructure and services. They argue that closer cooperation between the public sector and the for-profit private sector generates improved service quality and value for money in innovative ways (Willems, 2014; Hodge \& Greve, 2007; Andrews et al., 2015). Given their capacity to complement or even substitute governments' tasks, PPPs have become sophisticated and far-reaching organisations with huge financial and representative commitments in the name of citizens (Hodge \& Greve, 2007; Peters \& Pierre, 2010).

For the purpose of this study, we define the PPP model as a hybrid organisation that merges structures and resources previously employed by separate public and private entities (Shaoul et al., 2012). The model involves a long-term and non-hierarchical relationship (Weihe, 2006) that aims at risk sharing between partners (Bovaird, 2004), as well as co-produce and co-create of public services (Van Ham \& Koppenjan, 2001; Velotti et al., 2012).

Nonetheless, the implementation and management of PPPs are susceptible to a number of potentially problematic practices that need critical attention. In particular, one of the most widely shared critiques in the literature is the lack of accountability (Acar et al., 2008; Willems \& Van Dooren, 2011). This is the quality or state of PPPs of being answerable to the wide range of stakeholders (Freeman, 1984) and take responsibility for their behaviour and actions (Considine, 2002; Bovens et al., 2008). What these critiques have in common is the fear that PPPs tend to displace governments in many key decisions regarding the public interest that breaks the accountability link with constituencies and democratic institutions (Rhodes, 1997; Warner, 2010). Conversely, PPPs have been also accused to compromise private investments and expertise for the sake of short-term political pressures which encourage opacity in information for shareholders and financial intuitions' participation in partnerships (Shaoul et al., 2012).

These critiques raise serious questions about whether or not PPPs erode the accountability of each sector involved in the partnership, with ultimate repercussions to the system of accountability overall (Cuadrado-Ballesteros, 2014; Willems \& Van Dooren, 2011). Given that the literature of PPPs still yielding more theoretical questions than empirical investigations (Acar et al., 2008; Steets, 2010), how do we know these concerns are well grounded? If this is to happen, what are the accountabilities being eroded with PPPs anyway? And how these potential deficits can be addressed?

In order to answer these questions, we undertook a systematic literature review. We collected articles from recognised international social science journals from 1998 to 2017 through the employment of three comprehensive online search engines. We categorised and synthetized articles in four analytical themes: behaviour, information, evaluation and sanction. This framework is derived from the principalagent theory that points out the steps through which accountability manifest between the accountor - the agent that provides information on his or her behaviour to the the account-holder - the principal - that evaluates and sanctions it (Bovens et al., 2008; Steets, 2010; Schedler, 1999).

This provided us clarity and conceptual parsimony to map out the process through which accountability take place in practice in the PPPs of the articles reviewed. We then pro- ceed with the identification of the main account-holders that PPPs must cope with and classify their mechanisms of participation in the accountability process of PPPs to uncover potential deficits.

The state of the art of the PPP literature shows that accountability mechanisms that refer to the provision of information and evaluation of PPPs have been extensively covered, especially from a performance and financial perspective, whereas research on the behavioural dimension of PPP partners as well as the instruments to sanction them has been less explored empirically. Our analysis identifies some of the main account-holders that PPPs must deal with, from which formal, informal, market and internal account-holders standout. None of these seems to exert full control over the accountability mechanisms studied in the review. Accounholders do not possess sufficient means to hold PPPs fully accountable at their convenience. Thus, we argue that this picture reflects how accountability of PPPs unfolds in practice, in an unbalanced and chaotic way. However, this multiplicity and redundancy of account-holders with contradicting and overlapping demands of accountability may be preferable as they may compensate for each other's flaws. We advise further research on the ways how forums and their accountholders coordinate themselves to achieve interdependency and complementarity.

\section{Characteristics of accontability}

One of the first basic notions of the accountability concept is attached to that of being answerable to somebody for one's actions (Flinders, 2001). This supposes a relationship based on the principal-agent principle, which postulates a link between parties when one of them acts for or on behalf of the other (Ross, 1973; Jensen \& Meckling, 1976). Agents, then, are subject of accountability for the way how they comply with the rules and procedures of managing recourses of third parties as principals, and produce quality results for these (Steets, 2010). For Mulgan (2003), the concept of accountability is well embedded in this principal-agent logic as it involves social interactions and exchanges that come from the rights on the part of the account-holder and the responsibilities of the accountor.

The relationship of accountability has several defining features that have to be considered when analysing the concept. First, to account is an external attribute which means that it is given to some other entity - individual or organisation - outside the one being held accountable (Ross, 1973). Second, accountability involves a process of social interactions of exchanges of information, feedback, and possible rewards. Third, accountability under these conceptual lenses implies an unequal relationship where the account-holder has some degree of authority over the accountor. Yet, this does not necessarily suggest a relationship based on power (Mulgan, 2003). It consequently follows that the accountor is an autonomous actor that may not necessarily act in the best interest of the account-holder, and this may exacerbate conflicts of interest between them and their expected utility (Hodge \& Coghill, 2007).

These interactions unfold in different forums of accountability. For Bovens (2010), a forum is a conceptual idea of the account-holder that can take the form of individuals, organisations, institutions or even virtual entities, like the public opinion where the accountability process can take place. In this sense, a forum acquires a connotation of a "regulatory space" (Willems \& Van Dooren, 2012, p. 1018) or the arena by which accountability is the currency of exchange. Five 
well defined forums of accountability tend to be dominant in the literature of public sector accountability: (1) the judicial forum that entails administrative tribunals and judicial courts; (2) the political forum, characterised by the citizens, parliaments, and politicians; (3) the market forum for shareholders, consumers, banks and rating agencies; (4) the administrative forum, where internal and external audits play a role; and (5) the public forum represented by the civil society, NGOs, and the mass media (Romzek \& Dubnick, 1987; Flinders, 2001; Bovens et al., 2008).

According to Peters \& Pierre (2010) and Willems \& Van Dooren (2012), three main functions can be distilled from these forums of accountability. First, the constitutional function which refers to the fact that public authorities can be held accountable for the abuse of power or corruption through a set of well-established procedures within the judicial forum of accountability. Second, the democratic function is related to the principle of representativeness in democracies, where citizens have the ultimate authority about public decisions. As such, the function is delivered primarily by the political and public forums of accountability. Third, the performance function of accountability refers to how well the agent meets its goals effectively and efficiently. This function is closely related to the market and administrative forums of accountability. Table 1 cross-classifies forums and dimensions of accountability. This gives us a clearer landscape for the identification and classification of account-holders in PPPs.

Table 1

Forums and dimensions of accountability

\begin{tabular}{ccc}
\hline Forums of & \multicolumn{2}{c}{ Functions of accountability } \\
accountability & Democratic Constitutional & Performance \\
\hline Public & $\bullet$ & $\bullet$ \\
Judicial & & $\bullet$ \\
Market & & $\bullet$ \\
Political & $\bullet$ & $\bullet$ \\
Administrative & & \\
\hline
\end{tabular}

Accountability in its most basic structure involves four basic mechanisms that dominate any given forum revised above. This structure entails a conventional principal-agent accountability chain that takes place in a forum in which the accountor - the agent - has an obligation to inform, explain and vindicate his or her behaviour to the account-holder - the principal - who in turn can pose evaluations and pass judgement to sanction or reward the accountor's behaviour (Bovens et al., 2008; Chen et al., 2013). Figure 1 illustrates the sequence of the accountability chain process.

The conceptualisation of accountability has been consistently clarified in the literature, but also widely categorised depending on the area of study. This increases complexity to pinpoint its main characteristics (Mulgan, 2003). Through the principal-agent lenses, however, the concept acquires the virtues of clarity and conceptual parsimony, from which researches can build on (Steets, 2010; Velotti et al., 2012).

\section{Methods}

In order to provide a state of the art on the topic of accountability in PPPs, this study incorporates a three-stage search process to conduct a systematic review of the literature (see Figure 2). Contrary to traditional literature reviews, the choice for a systematic review assisted in making the study more reliable and transparent in a reproducible way by
Figure 1

Mechanisms of the accountability process

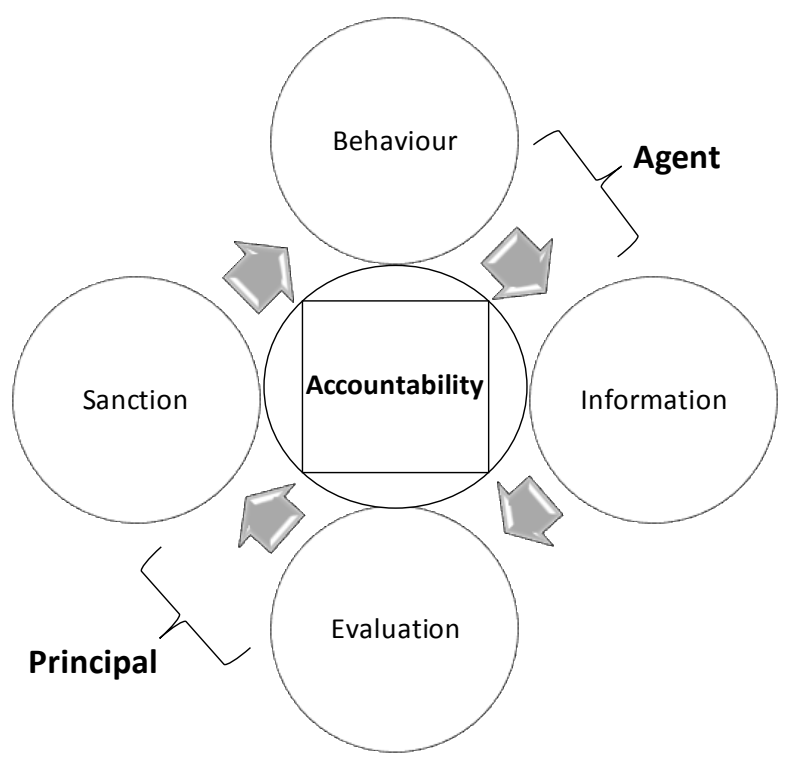

Source: Authors own elaboration based on Steets (2010).

employing an explicit selection process of articles (Voorberg et al., 2015). We describe the three-stage search process in the reminder of this section.

Figure 2

Flow diagram of the research strategy

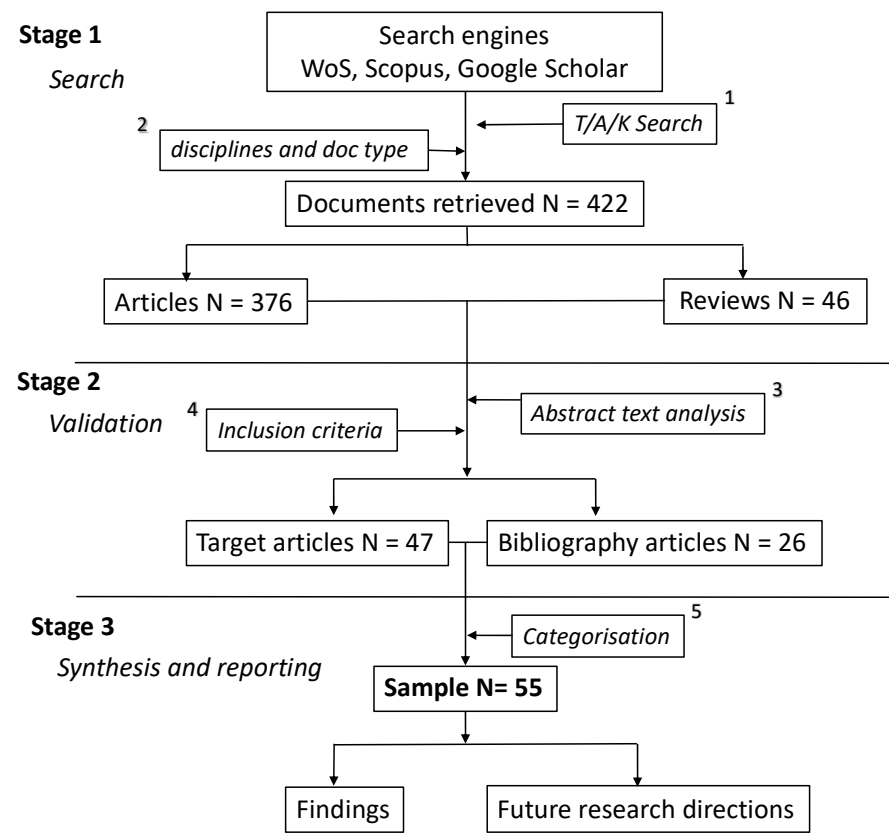

T/A/K - title/abstract/keywords

$\mathrm{T} / \mathrm{A} / \mathrm{K}$ - title/abstract/keywords

\subsection{Stage 1}

Drawing on previous systematic literature reviews (see De Vries et al., 2016; Voorberg et al., 2015), we focused on major online research engines for literature retrieval and assessment. This seemed reasonably, since coverage of PPPs in the literature has expanded considerably in the last decades (Andon, 2012; Steets, 2010). Our selection for research engines 
was based on suggestions from comparative citation analysis studies that evaluates the quality of different databases (see Levine-Clark \& Gil, 2008; Falagas et al., 2008; Harzing \& Alakangas, 2016).

We employed Thomson Reuters' Web of Science (WoS), because it has been well known among scholars as a source of quality research publications (Harzing \& Alakangas, 2016). WoS has been used extensively by scholars since 2004, which makes it a respectable source of information (Falagas et al., 2008). In addition, a more recent alternative database is Elsevier's Scopus that is the largest abstract and citation database of peer-reviewed literature. Scopus improves accuracy and coverage retrieving articles from a larger universe of indexed journals; it detects more citations, and as such, it may be a stronger database for social science disciplines that the former database (Falagas et al., 2008). Google Scholar is another rich source of references. It indexes many more titles than either of the other sources as it handles non-scholarly material in addition to the peer-reviewed journals (LevineClark \& Gil, 2008).

Google Scholar has been criticised because of its lack of search accuracy and tendency to retrieve low quality publications (Harzing \& Alakangas, 2016). Recent research, however, has found that Google Scholar displays stability over time in its results and offers a non-biased comparison across disciplines (De Winter et al., 2014; Harzing \& Alakangas, 2016). Moreover, in these comparison studies authors have concluded that Google Scholar provides broader coverage for most disciplines and that the WoS and Scopus can provide complementary results. This makes the three of them suitable for a comprehensive search of literature (Harzing \& Alakangas, 2016; Levine-Clark \& Gil, 2008).

In order to facilitate a coordinated search of publications of our interest, we used the software Publish or Perish that offers extensive data import facilities from multiple search engines. It provides the ability to import articles from Scopus, WoS and Google Scholar simultaneously and it avoids duplication of publications (Harzing \& Alakangas, 2016).

We carried out the study under the title/abstract/keyword field of the three major online search engines simultaneously. The time frame for the study covered publications from all years prior to 2018, providing sufficient span to enable a farreaching analysis. To increase the quality of the articles reviewed, the search was also limited to peer-reviewed journal articles and we excluded from the review no indexed journals, comments, book reviews, editorials, short notes and columns.

The search keywords included "accountability" which was limited to the area of PPPs by using the keyword "publicprivate partnerships" with the document type of "article". The search was set up for the disciplines of "social science" in general, and "business, management and accounting" in particular. We also opted to retrieve only articles in "English" language.

Given that any collaboration or agreement between the public and corporate sector may be casually categorised as a partnership (see Savas, 2000), a comprehensive search of publications was carried out including different procurement model who are generally associated to the PPP term like "contracting-outs", "joint ventures", and "cross-sectoral collaborations" (Weihe, 2006; Hodge \& Greve, 2007). This search yielded 422 articles, from which Scopus retrieved 201 items, WoS 171, and Google Scholar 70.

\subsection{Stage 2}

We evaluated articles against a set of inclusion criteria based on the principles of systematic reviews from Tranfield et al. (2003). We screened titles and abstracts from articles and read the full text when deemed necessary. Selection was undertaken ensuring three main criteria points: Firstly, that the articles were focused on PPPs or public-private collaborations and not on public-public, public-civil, private-civil, or private-private partnerships (Weihe, 2006). Secondly, that the articles included - substantively or moderately - discernible procedures and mechanisms from the accountability process already revised above in Figure 1. Thirdly, those articles were indexed in both the Journal Citation Reports (JCR) that rank the importance of a journal within the database of WoS, and the SCImago Journal Rank (SJR) that categorises journals by prominence and reputation within the database of Scopus (Levine-Clark \& Gil, 2008). In doing so, we assured that the journals of the articles in our sample hold a relative influence and prestige within their academic field. We dropped publications of no indexed nature. Publications recorded outside these venues were not counted in the sample.

To draw together a comprehensive set of relevant literature, we also included articles and books that were cited in the articles we reviewed and were of our interest to be included in the final selection of publications. We considered the sample size sufficiently large when new articles no longer added new perspectives on accountability arrangements in PPPs. The final number of articles effectively categorised in our four-step framework reached amounted to 55 publications.

\subsection{Stage 3}

The review found that the literature responds to very different forms of analysis, samples, and findings. The case study approach tends to be the primary data collection method. Authors' increased attention on the topic was evident by the high usage of qualitative methodologies such as interviews and surveys, while quantitative research approaches remained within the lowest number of publications. Theoretical or conceptual analyses performed in the rest of the sample in the form of literature reviews.

Given that most studies deal with research of a qualitative nature, the identification of specific units of analysis became challenging. Nonetheless, despite this lack of consistency, the articles showed PPP case studies that were fairly well aligned with elements around the four analytical themes of the accountability process. This allowed us to categorise articles and identify potential imbalances and trends on the coverage of accountability in the literature of public-private partnerships.

Within our categorisation process, studies whose accountability explanation was focused - directly or indirectly - on mechanisms that PPPs use to provide information to the different account-holder forums were allocated in the section of "Information". Contributions that referred to partners' behaviour, the role of authority and how these affect processes of accountability were grouped to the corresponding category of "Behaviour". Studies on accountability that centred on the mechanisms by which PPPs can be evaluated against a set of criteria were grouped in the "Evaluation" section. Finally, articles in which we could find some indications of disciplinary measures for PPPs, either as a result of poor performance, illegal practices, or public discontent, were classified in the section of "Sanction". Table 2 contains a detailed categorisation of the articles reviewed as well as their methodologies 
employed.

Table 2

Systematic review studies

\begin{tabular}{|c|c|c|c|c|c|}
\hline Authors & Behaviour & Information & Evaluation & Sanction & Method of analysis \\
\hline 1 Acar \& Robertson (2004) & $\bullet$ & & & & QL \\
\hline 2Acar et al. (2008) & & - & - & & $\mathrm{QL}$ \\
\hline 3 Acar et al. (2012) & & & & - & $\mathrm{QL}$ \\
\hline 4Agyenim-Boateng et al. (2017) & & - & - & & $\mathrm{QL}$ \\
\hline 5 Andon (2012) & & - & - & & EX \\
\hline 6 Andrews et al (2015) & - & - & & & QL \\
\hline 7Bardach \& Lesser (1996) & & & & - & co \\
\hline 8Baru \& Nundy (2008) & & - & & & QL \\
\hline 9Benish (2014) & - & - & & & $\mathrm{EX}$ \\
\hline 10Benner et al. (2004) & & & & - & EX \\
\hline 11 Bloomfield (2006) & - & - & - & - & QL \\
\hline 12Bovaird (2004) & - & - & & & $\mathrm{CO}$ \\
\hline 13Bradford (1983) & & - & - & & QL \\
\hline 14Brinkerhoff \& Brinkerhoff (2011) & - & - & & & QL \\
\hline 15 Broadbent \& Laughlin (2003) & & & - & & $\mathrm{EX}$ \\
\hline 16Cäker \& Nyland (2017) & - & - & & & QL \\
\hline 17Caperchione et al. (2017) & & & - & & EX \\
\hline 18Chen \& Hubbard (2012) & & - & & & QL \\
\hline 19 Chen et al. (2013) & - & & & - & EX \\
\hline 20 Considine (2002) & & - & & & QL/QN \\
\hline 21 Cuadrado-Ballesteros (2014) & & - & & & QN \\
\hline 22Da Cruz \& Marques (2011) & - & - & - & & $\mathrm{EX}$ \\
\hline 23Demirag \& Khadaroo (2011) & & - & - & - & QL \\
\hline 24Diggs \& Roman (2012) & - & - & & & $\mathrm{QL}$ \\
\hline 25Edwards et al. (2017) & & - & & - & QL \\
\hline 26Flinders (2005) & - & - & - & & QL \\
\hline 27Forrer et al. (2010) & & - & - & - & EX \\
\hline 28 Goodin (2003) & - & & & - & EX \\
\hline 29Halachmi (2002) & & - & & & $\mathrm{CO}$ \\
\hline 30 Hebson et al. (2003) & - & & & & QL \\
\hline 31 Higgins \& Huque (2015) & & • & & & QL/QN \\
\hline 32 Hodge \& Greve (2007) & - & & - & & $\mathrm{CO}$ \\
\hline 33Hodge \& Coghill (2007) & - & & & & QL \\
\hline 34Hodges \& Mellett (2012) & & - & - & & $\mathrm{QL}$ \\
\hline 35 Jos \& Tompkins (2004) & & - & & & $\mathrm{EX}$ \\
\hline 36 Joss (2010) & - & - & & - & QL \\
\hline $37 \mathrm{Ke}$ et al. (2017) & - & & - & & QL \\
\hline 38 Kort \& Klijn (2013) & & & - & & QL/QN \\
\hline 39Murphy (2008) & - & - & - & & $\mathrm{EX}$ \\
\hline 40Papadopoulos (2007) & - & & - & - & $\mathrm{EX}$ \\
\hline 41 Peters \& Pierre (2010) & - & & & & $\mathrm{CO}$ \\
\hline 42Reeves (2013) & & - & - & & QL \\
\hline 43Sands (2006) & - & - & & & CO \\
\hline 44Shaoul (2002) & & & - & & QL \\
\hline 45 Shaoul et al. (2012) & - & - & - & - & $\mathrm{EX}$ \\
\hline 46Siemiatycki (2007) & - & - & - & & $\mathrm{QL}$ \\
\hline 47 Steets (2010) & - & - & - & - & QL \\
\hline 48 Toms et al. (2011) & - & & - & & QL \\
\hline 49Van Ham \& Koppenjan (2001) & & - & & - & QL \\
\hline 50Velotti et al. (2012) & & - & & & QL \\
\hline 51 Warner (2010) & & - & & & EX \\
\hline 52 Weihe (2006) & - & & & & EX \\
\hline 53West (2005) & & & & - & QL \\
\hline 54Willems (2014) & - & & - & - & QL \\
\hline 55 Willems \& Van Dooren (2011) & - & - & & - & $\mathrm{QL}$ \\
\hline
\end{tabular}

"Note: $\mathrm{CO}=$ Conceptual; $\mathrm{EX}=$ Explorative; $\mathrm{QL}=$ Qualitative; $\mathrm{QN}=$ Quantitative

\section{Findings}

Accountability in PPPs is highly complex and difficult to trace without a framework for its analysis. Thus, we categorised and analysed the literature employing the four elements of the accountability chain process we described in section two of this review. This facilitated our task, because it provided conceptual clarity to our analysis. This framework allowed us to capture how accountability unfolds in a fundamental way for PPPs so we could identify more precisely key account-holders. In what follows, we describe these findings.

\subsection{Behaviour}

Despite its importance for accountability, the subject of behaviour is rarely studied in depth in the literature of PPPs (Ke et al., 2017). Contributions on behaviour seem to be scattered and they do not bring conclusive answers to the questions of how and according to whose standards PPPs should behave in practice. The set of literature that we have identified for this element of analysis, however, tend to focus on partners' characteristics that explain conducts and ac- tions, and possible conflicting interpretations of their roles. In this regard, there are two main inconsistencies for behaviour in PPPs that pertain to the nature of the public and private agents.

On the one hand, the so touted peculiarity of the crosssectoral partnerships is their horizontality in the decisionmaking procedures (Weihe, 2006; Hodge \& Greve, 2007). This feature of PPPs provides them organisational dynamism and flexibility contrary to the more rigid and hierarchical forms of procurement mechanisms traditional of for public services. However, flatter organisations like PPPs exacerbate remarkably the loss of control of public agents. Authors in the literature have raised several concerns about this problematic characteristic in partnerships (see Murphy, 2008; Siemiatycki, 2007; Willems, 2014) that is reflected in public sector representatives showing poor monitor mandates of their private counterparts (Benish, 2014; Bloomfield, 2006). This is a consequence of unresolved or loosely defined roles for the public agent to perform in flattened and hybrid organisational settings, which brings as a result public goals to be downplayed.

The absence of well-defined organisational structures in PPPs in terms of "who is accountable to whom?" challenges the public sector agents' mechanisms of vertical accountability, and thus it modifies their conventional and hierarchical behaviour when hold to account by their constituencies (Flinders, 2005; Papadopoulos, 2007; Peters \& Pierre, 2010). Accounts to their corresponding political and public forums experience severe limitations (Flinders, 2005). This has led to some authors (see Peters \& Pierre, 2010) to warrant about the democratic deficits in accountability that PPPs are prone to bring about, let alone the political costs. This is best exemplified by Willems \& Van Dooren (2011) who argue that the increased use of PPPs in some countries has undermined the direct control capacity of ministers. When parliaments hold their ministers to account, these can hardly uphold defence of their dependent departments and public officials involved in PPP projects. This is, the public and private boundaries in PPPs get so blurred that it is ultimately dicult for ministers to identify who is responsible for the good or bad outcomes of the partnership (Willems \& Van Dooren, 2011).

On the other hand, the private sector is also subject of different factors that influence the behaviour of its representatives in PPPs. In many case studies of the literature, the private sector has shown to be captured by corporate traditions that prioritise a rent-seeking behaviour (Toms et al., 2011; Benish, 2014). Contributions from Siemiatycki (2007), Shaoul et al. (2012) and Sands (2006) expose very well these practices that aim at satisfying exclusively performance functions of accountability. According to these authors, private partners behaviour is guided chiefly by the duty of performance accountability, because they handle resources that are under strong scrutiny from market forums like shareholders and financial institutions whose interest resides primarily on the return of investments.

These characteristics encourage the adoption of rentseeking behaviours and create considerable conflicts and dilemmas in the management of PPPs (Flinders, 2001). As it could be expected, PPPs put a considerable strain on the public ethos they are supposed to pursue (Shaoul et al., 2012; Hebson et al., 2003). This has led to instances where private firms' shareholders or financial institutions have gained great influence over the direction of PPPs (Shaoul et al., 2012).

After the review of articles clustered in this subsection, we noted that PPPs face a tug of war between preferences of corporate governance that support market forums of accountab- 
ility and that of the public sector traditions that uphold public and democratic forums of accountability (Shaoul et al., 2012). Some authors argue that this is a natural struggle in hybrid governance environments like cross-sectoral partnerships, because they are more fluid and uncertain organisations and where power is shared by partners with relatively equal standing (Bardach \& Lesser, 1996).

This places PPPs in problematic arenas since accountability calls provoke partners behaviour to collide instead of reinforcing each other (Acar \& Robertson, 2004). The structure of commands that otherwise would enable basic principles of answerability and responsibility is clearly absence in the PPPs reviewed from the literature (Mulgan, 2003). Participants' behaviour sway according to the expectations of their own sectoral account-holders, and as a result, the multiple, diverse, and conflicting expectations of constituencies in PPPs seems to create a precarious situation that runs against the main collaborative objectives of these organisations (Acar \& Robertson, 2004; Da Cruz \& Marques, 2011).

\subsection{Information}

The accessibility of reliable information is a pillar in the process of accountability (Schedler, 1999; Dubnick, 2005). Information is part of the compliance of rules and processes for the organisations (Steets, 2012) that account-holders are generally keen to enforce. As such, treatment of information figure prominently in the rules, and protocols of partnerships (Andon, 2012). PPP contracts define what needs to be communicated, the quality of information and even the level of transparency of information required (Reeves, 2013; Cuadrado-Ballesteros, 2014; Velotti et al., 2012). Therefore, the element of information has been quite well covered in the items reviewed for this study, whose major concerns tend to converge on the fact that information provided by PPPs do not meet requirements of the different account-holders.

In the different case studies of the literature, PPPs have provided ambiguous and unequal amounts of information about their operations. Some authors make accounts of this as the information asymmetry effect (Shaoul et al., 2012; Chen et al., 2013; Willems \& Van Dooren, 2011), that refers to the actions of the agent or accountor to produce and disseminate information at his own convenience (Steets, 2010). In PPPs, the partner who does bears the consequences of the information asymmetry is consequently vulnerable to the opportunistic behaviour of the counterparts that act on his behalf (Sands, 2006).

Baru \& Nundy's (2008) article on PPPs in the Indian health system is a good example of this. The authors described how the public agent in these partnerships dominated the project processes in terms of expertise and technical knowledge to the point that it caused severe concerns for the private sector that placed little trust and expectations for its participation in the venture. Murphy (2008), on the other hand, brought the case of Canadian infrastructure partnerships, where the private-sector managers took advantage of inexperienced public servants in each department of the partnership to limit reports and relevant information about the developments of the project. These examples tell us that information asymmetries place either the public or the private agent in a position to benefit their sectorial interest, which is in detriment for the overall goals of PPPs projects and their different bodies of account-holders (Steets, 2010).

We also found that in general the proliferation of case study articles in the literature deals almost exclusively with information aspects of financial and performance related is- sues like effectiveness, accounting and value for money of PPPs. This is an indication that PPPs present a strong emphasis on the provision of information that prioritises performance functions of accountability (see Siemiatycki, 2007; Shaoul et al., 2012; Hodges \& Mellett, 2012).

While it is acknowledged that performance data and financial statements are quite useful to assess results and enable shareholders to make better-informed investment decisions, this information is broadly impractical to satisfy constitutional and democratic functions of accountability, in which information interests reside in the way how partnerships handle public money, the social implications of the project and the decision making procedures (Da Cruz \& Marques, 2011; Edwards et al., 2017).

It should come as no surprise then, that there is a dearth of case studies in the literature analysing or comparing information of PPPs directed to parliaments, action groups, civil society or media, from which accountability demands are not a small issue (Benish, 2014; Sands, 2006). Citizens, users and recipients of PPP services cannot make reasonable informed decisions about the safety and fairness of PPPs if the only information available to them is not relevant or understandable (Baru \& Nundy, 2008; Shaoul et al., 2012). From our review in this subsection, it is clear that information asymmetry brings disadvantages to the public account-holders and undermines accountability as the essence of the public answering obligation (Forrer et al., 2010). Literature on public prisons (Sands, 2006), education (Edwards et al., 2017), and health (Baru \& Nundy, 2008) gives account on this deficit in accountability.

In addition, Siemiatycki (2007), Joss (2010) and AgyenimBoateng et al. (2017) explore the case for confidentiality in commercially sensitive information as the underlying motivation for PPPs' limitations in information. Confidentiality derives from PPP partners who are not legally subject to the Freedom of Information Act (Siemiatycki, 2007) or legal statutes alike in different countries. For instance, private actors in a partnership are not legally liable to provide information they might consider relevant for their competitors to take advantage of (Joss, 2010).

This reasoning is consolidated in many PPP projects and it has been nourished by the economic theory of property rights that postulates the importance of the protection of technical design and intellectual rights to uphold competitiveness in the market (Demirag \& Khadaroo, 2011). However, for some authors this clearly represents an inflection point for PPPs as deliverers of public goods (Siemiatycki, 2007). Confidentiality is capitalised by PPP decision-makers who cannot be held directly accountable to any electorate or group of social account-holders (Higgins \& Huque, 2015) like media or NGOs.

The lack of incentives and the higher transactional costs to disclose consistent, comparable, and understandable information for a number of forums remains debatable in PPPs (Shaoul et al., 2012; Reeves, 2013). Siemiatycki (2007) and Agyenim-Boateng et al. (2017) have severely critiqued PPPs' confidentiality agreements on the grounds that they not only lead to the impartial and discretional decision-making on behalf of the public, but it also hinders the collection of data for control evaluations.

Contrarily, a variant of this literature advocates for practices in confidentiality in PPPs. Claims tend to agree on that provision of more information about public-private associations does not necessarily produce better outcomes neither for the collaboration nor for the public goals (Halachmi, 2002; Jos \& Tompkins, 2004). For these authors, the design 
of more pluralistic forms of information would actually make PPPs too frail and too complex to operate effectively so as to offset their presumed benefits (Flinders, 2005).

In conclusion, the evidence provided by the literature in this subsection reports that information has been broadly skewed in favour of financial and performance aspects of the PPPs, ruling out the generation and dissemination of information that creates public value and public engagement (Considine, 2002; Diggs \& Roman, 2012). This practice has been reflected in the information asymmetry that characterises several PPP developments in the literature. Authors are aware that asymmetries stem from the quite diverse administrative natures of PPP partners, however administrative and market forums of accountability tend to dominate the process of information provision of PPPs.

\subsection{Evaluation}

As part of the accountability process, evaluations allow the establishment of benchmarks for comparison of how well the agent performed and achieved the objectives agreed with the principal (Kort \& Klijn, 2013; Solana et al., 2017). The evaluation processes of PPPs turned out to be extremely important for most of the articles reviewed in this study.

We first identified that PPPs' main goals have been broadened through the precept of "value for money" (VFM) (Andon, 2012). VFM recognises the optimum combination of cost and quality of services, while at the same time meeting the needs of end users (Caperchione et al., 2017). As an evaluation process for PPPs, it involves a public sector comparator (PSC) that calculates the cost of the partnership against a hypothetical scenario that calculates the net present value of the expected life cycle cost if the project had been built and managed by traditional procurement models (Reeves, 2013; Broadbent \& Laughlin, 2003).

In the case studies of the literature, policy-makers and practitioners agreed upon the assumption that the VFM evaluation is the most relevant assessment scheme for publicprivate partnerships being held accountable (Broadbent \& Laughlin, 2003; Murphy, 2008; Toms et al., 2011; Flinders, 2005). Since, this evaluation concentrates on aspects that can be easily quantied in terms of money, it has been widely used to prove feasibility and affordability of partnership projects (see Demirag \& Khadaroo, 2011; Reeves, 2013; Willems 2014; Toms et al., 2011).

However, the VFM evaluation has been subject of critique. For instance, articles related to PPPs in areas like public transportation (Shaoul, 2002), water provision services (Reeves, 2013) and, most prominently, infrastructure projects (Siemiatycki, 2007) cast a shadow over the VFM precept for evaluations. Concerns arise in relation to its reliability (Murphy, 2008; Flinders, 2005). In particular, Shaoul's (2002) research on PPPs of the UK public transport system shed light on how elements of the evaluation like discount rate, transaction costs, and risks allocation - among others are prone to manipulation. This is supported by Reeves's case study of Irish partnerships in the provision of water (2013), who argues that evaluations of PPPs through VFM can be used to swing decisions in favour of the partnership alternative over other more traditional procurement models. A number of other authors have provided evidence on how malleable public infrastructure projects can be due to erroneous or biased evaluations of VFM (Toms et al., 2011; Hodge \& Greve, 2007).

It follows, then, that the VFM as a tool for PPPs accountability has had an undesirable impact on the governance of these organisation leading to projects fell short of public expectations (Hodge \& Greve, 2007; Murphy, 2008; Hodges \& Mellett, 2012). This is mostly reflected in project delays and cost overruns that prevail in most of the literature of failed PPPs (Andon, 2012; Shaoul et al., 2012).

In this analytical subsection, we also noted that some authors argue that PPP evaluations concentrate on factors that can be easily quantified and that scarce attention is given not only to issues of quality, but also to the project's potential externalities (see Hodge \& Greve, 2007; Da Cruz \& Marques, 2011). The fact that some factors are much easier to evaluate than others has led to the development of faulty evaluations (Reeves, 2013). On this, Steets (2010) asserts that it will be much simpler to asses and judge "financial returns of an investment than to measure the social or environmental effects of an investment decision" (p. 26). This tell us a bit more about why evaluations for PPPs focus exclusively on performance functions of accountability, which have taken precedence over more practical and useful assessments for the public and politic forums of accountability.

For some articles reviewed, PPP evaluations are incomplete without considering broader social costs and benefits. This echoes Andon's (2012) warrants for policy-makers and practitioners to look beyond the mere "technicalities of partnerships" (p. 905). Assessments of PPPs on affordability and feasibility should lie on whether or not the partnership's project has lower total social costs in terms of environmental impact, space or natural resources overuse (Hodge \& Greve, 2007; Da Cruz \& Marques, 2011). For Agyenim-Boateng et al., (2017), without these factors for evaluation, conventional evaluations of PPPs divert our attention from what makes the PPP a truly public value booster with potential negative consequences for the final users and/or taxpayers.

The tendency of PPPs to be evaluated for performance purposes can be widely observed in the policy rhetoric of infrastructure projects in the UK, the USA, the Netherlands and Australia (Hodge \& Grave, 2007; Siemiatycki, 2007). Accountability scholars like Dubnick (2005) have presented critiques to this practice of stretching the concept of performance almost to the point of substitution of public accountability. For Dubnick (2005), the presumed relationship between concepts remains unarticulated and untested to give it for granted in cross-sectoral associations.

Moreover, in the articles we analysed for this subsection, we also noted that authors raise concerns on the lack of expost evaluations (Acar et al., 2008; Willems 2014). Andon's (2012) review identifies a plethora of case studies with evaluations for PPP projects before the kick-off of their operations. In these studies, VFM assessments stands out as part of the ex-ante evaluations, while assessments of the development of the projects or once they have finished are notably scant. For these authors, PPP projects are densely evaluated at their early stages and not on how they fared after the operations have concluded - let alone if they accomplished their initial objectives.

Ke et al. (2017) contend that the scarcity of ex-post evaluation is justified, because in practice only few PPP projects have reached mature stages. Bloomfield (2006) and Shaoul et al. (2012) agree on this point by arguing that by the very long-term nature of PPPs - usually up to 25 or 30 years - evaluations become problematic. Evaluations are hardly feasible to undertake by the same public entities that negotiated initially the partnership or those who concluded it (West, 2005; Willems, 2014). Nevertheless, Forrer et al. (2010) argue that assessments of PPPs do not have to wait until their termination as these could be undertaken diligently at differ- 
ent stages of the development of the collaboration. Murphy (2008) and Andon (2012) listed some of these potential evaluation points: (1) at the point of requesting for proposals and bids to select a private partner; (2) at the point of the awarding of the contract; (3) at the point of the development of the project; and (4) at the point of the conclusion of the project.

On the whole, the current body of literature clustered for the evaluation subsection of this paper is well developed in terms of performance assessments. The tendency of PPPs to being evaluated in terms of technical issues as the only way to keep them accountable has been found by some authors as biased. Despite this information is critical for a wide array of market account-holders such as financial institutions, shareholders and rating agencies, the literature have also warned about this information to be susceptible of manipulation. Performance-driven accountability tools that assess only what can be monetarised have led to a detriment of more traditional mechanisms of accountability that meet the requirements in terms of externalities and the social cost generally placed by the public or political forums of accountability (Goodin, 2003; Hodge \& Coghill, 2007). These contributions remind us that there is more to accountability than performance when it comes to PPPs.

\subsection{Sanction}

In accountability, the element of sanction enables the account-holder to signal whether or not he or she agrees with the accountor's performance and behaviour (Steets, 2010). Sanction culminates the cycle of the four elements of the accountability chain process that we have reviewed - behaviour, information, and evaluation.

The literature is remarkably light on studies related to sanctions as well as incentives to strengthen accountability in practice. The shortage of empirical studies of sanctioning mechanisms for PPPs comes as a surprise, given the increased reference in the literature to failed PPP case studies (see Bloomfield, 2006; Joss, 2010; Chen et al., 2013). Nonetheless, we did find some relevant contributions of authors that have identified and discussed potential mechanisms of sanction for PPPs. We noted that these contributions were quite theoretical, and mainly derived from the accountability traditions of the public and private sectors rather than being empirically proved in case studies.

In this section, we draw four main sanctioning mechanisms identified for PPPs, from which the first three - legal/fiscal, funding cuts and elections - belong to potential sanctions from principals outside PPPs, while the rest - disciplinary measures, voice and withdrawal - can be exerted from principals within PPPs.

We first found that that the literature has strong considerations for the role of the judicial review, because it is meant to be one of the strongest account-holders for the legal enforcement and control of PPPs (Steets, 2010; Bovens et al., 2008). This is the accountability to meet constitutional standards through courts and tribunals that impose strict formal standards for decision-making and the prevention of conflict of interest (Hodge \& Coghill, 2007; Willems \& Van Dooren, 2012). In this regard, contributions from West (2005) and Demirag \& Khadaroo (2011) broach the issue of legal and fiscal sanctions that could be imposed on PPPs that breach norms and laws. The authors argue that sanctions through legal and fiscal measures potentially induce performance or compensate for non-performance.

Nonetheless, these potential sanctioning mechanisms can be contrasted by case studies of PPPs in Flemish school in- frastructure (Willems, 2014) and Australian infrastructure PPPs (Hodge \& Coghill, 2007). These case studies have shown that the judicial forum of accountability have played a less visible role for two main reasons. First, because PPPs are contractually designed in ways that prevent them to getting involved with judicial forums in case of conflict, because judicial accountability tends to be time-consuming and paralytic for PPP projects (Benish, 2014; Hodge \& Coghill, 2007). Secondly, because countries have not consolidated legal frameworks for PPPs that effectively enforce partnerships to constitutional compliance (see also Chen et al., 2013; Ke et al., 2017). This stream of the literature has shown that legal sanctioning varies greatly between countries, and their capacity as forums of accountability is rendered unstable (Steets, 2010).

Moreover, free and fair elections are one of the most common and effective mechanisms that help to discipline and direct the actions of public officials in democracies. Elections have the capacity to sanction poor behaviour and keep the political leaders accountable for the preferences of the electorate (Goodin, 2003; Bardach \& Lesser, 1996). Despite that electoral process is generally considered the mechanism through which the democratic function of accountability is delivered (Steets, 2010), when the mechanism is stretched to PPPs it finds some obstacles.

Forrer et al. (2010) argue that elections are a potential mechanism of sanction for PPPs, whereby citizens can make their choices on whether or not to re-elect those politicians who backed up a particular PPP project. However, Benner et al. (2004) counterargue this assumption. They point out that elections are able only to held elected officials accountable. The mere identification of public officials does not necessarily enable a direct sanction. Public agents involved in PPPs are appointed bureaucrats, and these are not directly accountable to the public through elections (Benner et al., 2004).

Some authors have identified funding or budget cuts as potential sanctioning measures. Funding cuts can be easily employed and controlled on the side of account-holders either public or private in PPPs (Bovens, 2005, 2010). But, the financial control as a corrective behaviour measure has not been explored in depth. Case studies from Shaoul et al. (2012), Bardach \& Lesser (1996) and Edwards et al. (2017) revealed a number of funding instruments for PPPs, but they did not go further to explain the conditions attached in cases where the partnerships do not meet their goals.

On the other hand, from an internal perspective, managers of PPPs - whether from the public or private sector - can impose disciplinary sanctions to correct PPPs' behaviour. Joss (2010) contends that this type of mechanism performs best in hierarchical settings, in a downward direction. In this regard, managers can generally resort to punitive measures for their staff to account and sanction them if rules or protocols are breached (Steets, 2010; Shaoul et al., 2012). However, these authors find that due to the boundary-crossing nature of partnerships, the absence of formal authority and the fuzziness of power between multiple actors make this type of sanction for PPPs far less useful. Then, disciplinary sanctions within partnerships seem to become widely debated among academics, but it is not so among practitioners as the case studies reviewed shown.

Drawing on Hirschman's (1970) seminal work "Exit, Voice and Loyalty", Acar et al. (2012) propose an additional sanctioning mechanism related to the disengagement and withdrawal of partners and/or stakeholders from PPPs. This type of sanction reflects a form of disapproval, but also a type 
of disciplinary measure. A powerful sanctioning mechanism to influence an entity is the option to stop engaging in it or simply not to comply with its main decisions (Steets, 2010). In particular, the article from Chen et al. (2013) construe an exemplary case study for public accountability. Citizens from Taiwan and China opposed to PPPs of road developments since the costs of these projects were imposed on them. Citizens as well as civil society groups raised their voice and discontent by preventing the use of roads, and thus boycotting the service of road toll charges. This practice of sanctioning mechanism seriously undermined the legitimacy and reputation of the PPPs in charge of the road developments.

All in all, the identification of these different sanctioning mechanisms in the literature has shown an interesting set of possibilities to discipline and influence PPPs - internally as well as externally. Unfortunately, as noted above, there is limited evidence on how these mechanisms are employed in real situations. Papadopoulos (2007) argues that actual employment of sanctions might not even be necessary in partnerships, but rather their "shadow" (p. 13) or their potential threat to be imposed. Papadopoulos' contribution is interesting in its own as it implies that accountability and its enforcement powers can work in a preventive manner instead of being retroactive. In other words, what matters is not the sanction itself, but its "intimidation" effects to prevent opportunistic behaviours in organisations and anticipate ex-post control by account-holders.

\section{Discussion}

Findings from the previous section reveal that PPPs are constantly being called to account from different forums of accountability and for different reasons. Because of this, it is unclear how exactly PPPs should handle conflicting accountability burdens and how accountability can make a positive difference towards PPPs' objectives (Jos \& Tompkins, 2004). The assemblage of all these forums and dimensions clearly makes accountability anything but straightforward for PPPs (Shaoul et al., 2012). And the question of "who is accountable, to whom, for what and how?" (Steets, p. 18) can turn into a major problem. However, we have grasped some interesting insights into this matter.

The articles reviewed show that citizens, civil associations, the media, and political parties wield demands on public and political accountability for PPPs (Willems, 2014; Benish, 2014; Forrer et al., 2010). These demands are sustained by the democratic function of accountability that stems from the involvement of governments in cross-sectoral collaborations; through the delegation of authority from the public to the governments, which, in turn, delegate authority to the public officials participating in PPPs. This is the transfer of public accountability demands to the realm of PPPs accountability. We identify this type of principals as the informal accountholders of PPPs (c.f. Steets, 2010), because their obligations and rights remain quite disputed within the PPPs literature despite their normative importance (Rhodes, 1997; Bovens et al., 2008).

The informality of the implicit delegation of authority from the public to PPPs should not downplay petitions of accountability of informal account-holders (Blanchard et al., 1998). This is, the public sector remains fully fledged in its responsibility for the services and infrastructure despite it does not deliver them alone. Our analysis of sanction mechanisms of accountability reveals that, in general, PPPs do not express major concerns about groups of informal account-holders unless they create momentum and exert great pressure and discon- tent against PPPs' developments (see Chen et al., 2013; Acar et al., 2008). In other words, the informal account-holders do not possess sufficient means to hold PPPs accountable, but they can resort to withdrawal, protests or boycotts as potential sanctioning mechanisms and influence PPPs behaviour.

The literature also shows that PPPs are subject of internal account-holders that make calls for accountability. These principals can be the manager or director of the partnership, but also the public official and the private sector that collaborate together. Internal account-holders of an organisation are generally specified by means of contracts, protocols or guidelines that estipulate the type of interaction they are meant to develop (Caperchione et al., 2017).

We found that internal account-holders play a prominent role in our analysis of behaviour and information. In this regard, partners have to adhere to codes of conduct and make sure their counterparts follow the same rules, and this is not possible without mechanisms of provision of information (Benner et al., 2004). Due to the nature of partnerships by including many actors in complex, dynamic and evolving relationships - the role of internal account-holders has become fuzzy and contested. Then, information asymmetries tend to dominate among partners of the partnership (Bradford, 1983; Baru \& Nundy, 2008). This has prevented the public sector representatives to obtain enough information about the PPPs activities. They are, to a certain extent, limited to see the bigger picture of the partnership, and thus, accounts to their corresponding political and public forums of accountability is limited (Flinders, 2005).

Partnerships, moreover, experience liability to the judicial courts and parliaments, ombudsmen, audit offices and anticorruption agencies that preside over administrative and judicial forums of accountability (Broadbent \& Laughlin, 2003). We coined these as the formal account-holders of PPPs. They are by far the most formalised group of account-holders that partnerships have (Willems, 2014). Yet, the effective role of the formal principals in the literature is mixed. In our sanction analysis, some authors tend to agree that formal accountholders can set out effective and strict rules for behaviour and sanction systems for PPPs (Benish, 2014). However, the sanction analysis also shows contradicting evidence agents this assumption, due to the poor enforcement of judicial forums of accountability and the absence of legal frameworks in countries where partnerships are becoming the norm (Chen et al., 2013; Ke et al., 2017).

The PPP model also has to comply with traditions of corporate accountability. Our analysis of information provision and evaluation of PPPs revealed the strong influence of the market account-holders (c.f. Benner et al., 2004). This group of account-holders tends to elicit financial and performance information, as well as VFM evaluations of PPPs. As such, this group has been gaining prominence in the accountability of partnerships (Goodin, 2003; Toms et al., 2011). Although authors are aware that information for performance and financial concerns of PPPs is not necessarily wrong on their own, its exclusive promotion as the only mechanisms of accountability for PPPs has obfuscated legitimate demands for accountability coming from the other forums with a stake in the partnerships (Willems \& Van Dooren, 2011).

From this literature review, we have not only identified some of the main account-holders that PPPs must cope with in practice, but also the mechanisms they tend to employ to participate in the process of accountability of PPPs. While the informal account-holders engage effectively only in processes of accountability related to sanctioning, the internal accountholders play a role in the behaviour and information mech- 


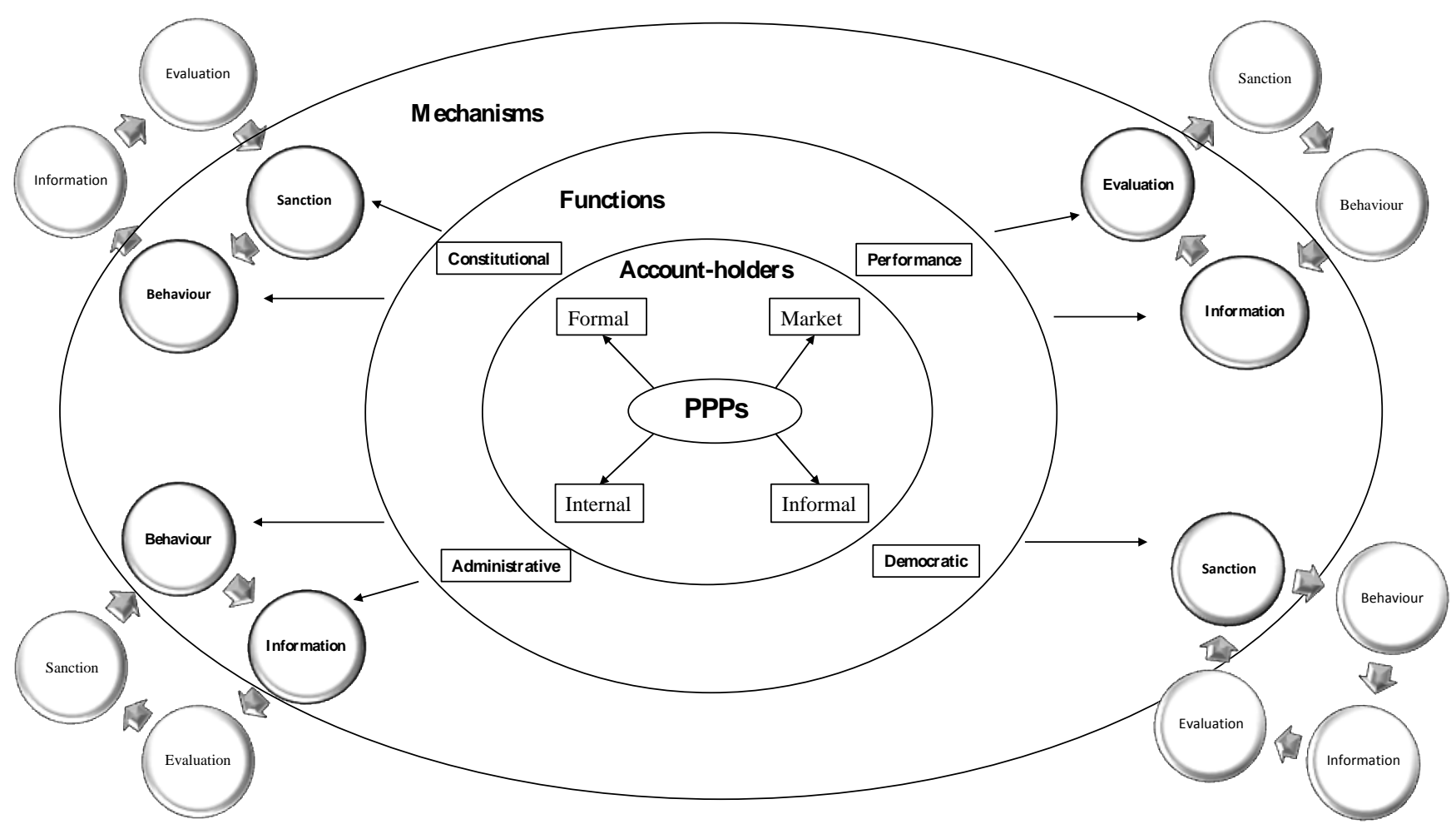

Source: Author's own elaboration.

anisms. Moreover, evaluation and information mechanisms of accountability tend to be dominated by market accountholders, and the formal account-holders represented by the judicial forum addresses accountability of PPPs through the sanctioning and behaviour mechanisms.

We observe that with the exception of informal accountholders, the rest tend to focus on at least two mechanisms of the accountability chain process. What is noteworthy, however, is that none the of account-holder groups in our review seem to have developed a set of processes that allow them to rely on all the four mechanisms of accountability available. Figure 3 illustrates this dynamic, yet patchy process of accountability in PPPs. Account-holders have not been able to devise innovative and efficient ways to exploit the full range of possible mechanisms of accountability, instead they focus on a limited and determined set of processes that has created accountability deficits in detriment mostly for the public and political forums of accountability. These findings may confirm concerns about accountability being eroded but not necessarily by the simple existence of PPPs, rather by the specific selection of accountability mechanisms though which account-holders participate in the process.

These findings reflect how accountability of PPPs unfolds in practice, in an unbalanced and chaotic way. Accountholder groups can pull contradictory and overlapping accountability demands, which generates conflict and deficits. However, we think that this multiplicity of forums of accountability is preferable in principle to more narrowed approaches to accountability, because it can compensate for the flaws of other account-holders (c.f. Willems \& Van Dooren, 2012). PPPs are embedded within old and traditional mechanisms of accountability, and we think this will hardly change in the near future. Thus, a rebalancing act for more effective, horizontal, and integrative accountability can be feasible as long as it emerges from the old modes of traditional accountability. The current situation of PPP can exploit the virtues of redundancy or "many eyes" (Papadopoulos, 2007, Shaoul et al., 2012). To say that barely nothing could escape the eyes of many account-holders, and when one succumbs another can step in and prevent overall accountability deficits (Mulgan, 2003).

In doing so, a well-coordinated set of account-holders would mitigate the intrinsic information asymmetry among them and the PPP by offering extra points of complementarity and interdependency (Willems \& Van Dooren, 2012). This will turn the seeming complexity of accountabilities into an advantage. We acknowledge that for PPPs it impossible to do justice to all of the accountability forums, but these findings may imply that the creation of consensus among accountability forums and their account-holders would be in the best interest of PPPs to push forward development projects and derive greater benefits of accountability and legitimacy. Benner et al (2004) have provided examples of multi-sector organisations conducting multi-stakeholder dialogues to clarify their roles and interest in terms of information so to agree on a coherent set of accountability demands that maximises the benefit as account-holders. This can be replicated for PPPs.

\section{Conclusions}

This study reviewed and discussed accountability around four primary elements of analysis: behaviour, information, evaluation, and sanction. These elements pertain to the traditional accountability chain process under the principal-agent theory that allows straightforward analysis in organisational settings. 
The literature has shown that concerns about accountability being eroded are well grounded. Especially, the public and political forums of accountability play a less important role. However, this is by no means due to the mere existence of PPPs. We argue this is due to the lack of coordination of account-holder forums that has privileged accountability for a limited array of account-holders generally pertaining to the market forums of accountability.

Our analysis identifies some of the main accountability forums and their account-holders that PPPs must deal with in practice. We found that none of these account-holders seems to control the four mechanisms of the accountability chain process fully. They do not possess sufficient means to hold PPPs entirely accountable at their convenience. Instead, each forum of account-holders focuses on at least two mechanisms of accountability. The implication of this is that accountability of PPPs may unfold in disorderly ways, with contradictory and overlapping demands. In spite of this, we argue that this complexity can turn into an advantage if the interdependency between forums is coordinated and their strengths complemented.

We notice that while there has been important work carried out in the literature, we have actually only begun to connect the dots of every piece of the accountability puzzle in PPPs, but much work is left. A challenge for future researchers will be to explore in depth how forums of accountability in PPPs can develop interdependency to complement their different requirement of accountability, as it has been argued. The literature would also benefit from longitudinal research that would allow the comparison of account-holders and their mechanisms of accountability over the time. This is at the different stages of development of PPPs. Similarly, this also goes for the urgent need of more ex-post studies of PPPs. Treatment of accountability in these two main fronts promises a fertile research agenda for the field.

This review has some limitations. First, the categorisation exercise of articles in four analytical themes could have been exposed to our subjective interpretation of how each element operates in PPPs. We are aware that articles could have been classified in multiple ways, perhaps leading to slightly different conclusions. Second, while aiming for a comprehensive coverage of publications, the selection of articles could have failed to capture broader perspectives for analysis. This may explain why in our review, case studies of PPPs in infrastructure projects were dominant. Third, although we put great effort in the selection of quality publications from international social science journals, this review may not reflect the diversity of experiences and views on the topic reflected in journals that do not met our selection criteria.

Finally, in times where PPPs have shown mixed track record in their effectiveness, researchers and practitioners alike still struggling to define the right combinations of accountability mechanisms that should permeate these organisations. For practitioners and scholars, making sense of a mass of often-contradictory and disperse body of literature has become progressively harder. Evidence underpinning the promotion and creation of PPPs as public good promoters has been questioned, for inadequate or incomplete, and that has seriously impeded policy formulation and implementation on the matter (Willems, 2014; Flinders, 2005; Considine, 2002). Thus, despite our limitations, this systematic literature review is both timely and important as it provides fresh insights into the elusive concept of accountability in hybrid forms of governance. We think our analysis no only contributes to the enrichment of the knowledge base of cross-sectorial partnerships in a more comprehensive and coherent manner, but it also informs policymaking and practice about the threats and opportunities that accountability brings along with PPPs.

\section{Funding}

Ministerio de Economia y Competitividad, Proyecto Collabdeb (CSO2016-80823-P).

\section{Conflict of interests}

The authors have no conflict of interests to declare.

\section{References}

Acar, M., \& Robertson, P.J. (2004). Accountability challenges in networks and partnerships: Evidence from educational partnerships in the United States. International Review of Administrative Sciences, 70(2), 331-344. https://doi.org/ 10.1177/0020852304044260

Acar, M., Guo, C., \& Yang, K. (2008). Accountability when hierarchical authority is absent: Views from public-private partnership practitioners. Public Organization Review, 12(2), 157-174. https://doi.org/10.1007/s11115-011-0169-0

Acar, M., Guo, C., \& Yang, K. (2012). Accountability in voluntary partnerships: To whom and for what? Public Organization Review, 12(2), 157-174. https://doi.org/10.1007/ s11115-011-0169-0

Agyenim-Boateng, C., Stafford, A., \& Stapleton, P. (2017). The role of structure in manipulating PPP accountability. Accounting, Auditing and Accountability Journal, 30(1), 119144. https://doi.org/10.1108/AAAJ-01-2014-1590

Andon, P. (2012). Accounting-related research in PPPs/PFIs: Present contributions and future opportunities. Accounting, Auditing and Accountability Journal, 25(5), 876924. https://doi.org/10.1108/09513571211234286

Andrews, R., Esteve, M., \& Ysa, T. (2015) Public-private joint ventures: Mixing oil and water? Public Money \& Management, 35(4), 265-272. https://doi.org/10.1080/ 09540962.2015.1047267

Bardach, E., \& Lesser, C. (1996). Accountability in human services collaboratives - For what? and to whom? Journal of Public Administration Research and Theory, 6(2), 197-224. https://doi.org/10.1093/oxfordjournals.jpart.a024307

Baru, R.V., \& Nundy, M. (2008). Blurring of boundaries: Public-private partnerships in health services in India. Economic and Political Weekly, 43(4), 62-71. JSTOR, Available at: www.jstor.org/stable/40277081 [Accessed 10.11.2018]

Benish, A. (2014). The public accountability of privatized activation - the case of Israel. Social Policy and Administration, 48(2), 262-277. https://doi.org/10.1111/spol.12060

Benner, T, Wolfgang, H.R., \& Martin, J. (2004). Multisectoral networks in global governance: Towards a pluralistic system of accountability. Government and Opposition, 39(2), 191-210. https://doi.org/10.1111/j.1477-7053. 2004.00120.x

Blanchard, L.A., Hinnant, C.C., \& Wong, W. (1998). Market-based reforms in government: Toward a social subcontract? Administration \& Society 30(5), 483-512. https: //doi.org/10.1177/0095399798305001

Bloomfield, P. (2006). The challenging business of longterm public-private partnerships: Reflections on local experience. Public Administration Review, 66(3), 400-411. https: 
//doi.org/10.1111/j.1540-6210.2006.00597.x

Bovaird, T. (2004). Public-private partnerships: From contested concepts to prevalent practice. International Journal of Administrative Science, 70, 199-215. https://doi.org/10. $1177 / 0020852304044250$

Bovens, M. (2005). 'Public Accountability', in E. Ferlie, L. E. Lynne, \& C. Pollitt (Eds), The Oxford Handbook of Public Management. 182-208. Oxford, New York: Oxford University Press.

Bovens, M., Schillemans, T., \& Hart, P. 't. (2008). Does public accountability work? An assessment tool. Public Administration, 86(1), 225-242. https://doi.org/10.1111/ j.1467-9299.2008.00716.x

Bovens, M. (2010) Two Concepts of Accountability: Accountability as a Virtue and as a Mechanism. West European Politics, 33(5), 946-67. https://doi.org/10.1080/01402382. 2010.486119

Bradford, C. (1983). Private sector initiatives and public sector accountability: A case study of contracting with City Venture Corporation. Journal of the American Planning Association, 49(3), 326-335. https://doi.org/10.1080/ 01944368308976559

Brinkerhoff, D.W., \& Brinkerhoff, J.M. (2011). Publicprivate partnerships: Perspectives on purposes, publicness \& good governance. Public Administration \& Development, 31(1), 2-14. https://doi.org/10.1002/pad.584

Broadbent, J., \& Laughlin, R. (2003). Public private partnerships: An introduction. Accounting, Auditing \& Accountability Journal, 16(3), 332-341. https://doi.org/10.1108/ 09513570310482282

Cäker, M., \& Nyland, K. (2017). Inter-Organizational cooperation challenging hierarchical accountability: The dominated actors in a municipal joint venture. Financial Accountability and Management, 33(1), 102-120. https://doi.org/ 10.1111/faam.12115

Caperchione, E., Demirag, I., \& Grossi, G. (2017). Public sector reforms and public private partnerships: Overview and research agenda. Accounting Forum, 41(1), 1-7. https: //doi.org/10.1016/j.accfor.2017.01.003

Chen, C., \& Hubbard, M. (2012). Power relations and risk allocation in the governance of public private partnerships: A case study from China. Policy and Society, 31(1), 39-49. https://doi.org/10.1016/j.polsoc.2012.01.003

Chen, C., Hubbard, M., \& Liao, C.-S. (2013). When publicprivate partnerships fail: Analysing citizen engagement in public-private partnerships - cases from Taiwan and China. Public Management Review, 15(6), 839-857. https://doi. org/10.1080/14719037.2012.698856

Considine, M. (2002). The end of the line? Accountable governance in the age of networks. Governance, 15(1), 2140. https://doi.org/10.1111/1468-0491.00178

Cuadrado-Ballesteros, B. (2014). The impact of functional decentralization and externalization on local government transparency. Government Information Quarterly, 31(2), 265-277. https://doi.org/10.1016/j.giq.2013.10.012

Da Cruz, N.F., \& Marques, R.C. (2011). Accountability and governance in local public Services: The particular case of mixed companies. Innovar, 21(42), 41-54. Available at: https://search-proquest-com.libproxy.ucl.ac.uk/docview/ 1677603490 ? accountid $=14511$ [Accessed 10.04.2017]

Demirag, I., \& Khadaroo, I. (2011). Accountability and value for money: A theoretical framework for the relationship in public-private partnerships. Journal of Management and Governance, 15(2), 271-296. https://doi.org/10.1007/ s10997-009-9109-6

De Vries, H., Bekkers, V., \& Tummers, L. (2016). In- novation in the public sector: A systematic review and future research agenda. Public Administration, 94(1), 146-166. https://doi.org/10.1111/padm.12209

De Winter, J. C., Zadpoor, A. A., \& Dodou, D. (2014). The expansion of Google Scholar versus Web of Science: A longitudinal study. Scientometrics, 98(2), 1547-1565. https: //doi.org/10.1007/s11192-013-1089-2

Diggs, S.N., \& Roman, A.V. (2012). Understanding and tracing accountability in the public procurement process: Interpretations, performance measurements, \& the possibility of developing public-private partnerships. Public Performance and Management Review, 36(2), 290-315. https://doi.org/ 10.2753/PMR1530-9576360207

Dubnick, M. (2005). Accountability and the promise of performance. In search of the mechanism. Public Performance \& Management Review, 28(3), 376-417. JSTOR, www.jstor.org/stable/3381159

Edwards, D.B., DeMatthews, D., \& Hartley, H. (2017). Public-private partnerships, accountability, \& competition: Theory versus reality in the charter schools of Bogotá, Colombia. Educa tion Policy Analysis Archives, 25(10), 1-36. https: //doi.org/10.14507/epaa.25.2556

Falagas, M.E., Pitsouni, E.I., Malietzis, G.A., \& Pappas, G. (2008). Comparison of PubMed, Scopus, Web of Science, \& Google Scholar: Strengths and weaknesses. FASEB Journal, 22(2), 338-342. https://doi.org/10.1111/ j.1467-856X.2004.00161.x

Flinders, M. (2001) The Politics of Accountability in the Modern State. Aldershot: Ashgate.

Flinders, M. (2005). The politics of public-private partnerships. British Journal of Politics and International Relations, 7(2), 215-239. https://doi.org/10.1111/j.1467-856X.2004. 00161.x

Forrer, J., Kee, J.E., \& Newcomer, K. (2010). Publicprivate partnerships and the public accountability question. Public Administration Review, 70(3), 475-484. https://doi. org/10.1111/j.1540-6210.2010.02161.x

Freeman, R. E. (1984). Strategic Management: A Stakeholder Approach. Boston: Pitman Publishing.

Goodin, R.E. (2003). Democratic accountability: The distinctiveness of the third sector. Archives Europeennes de Sociologie, 44(3), 359-396. https://doi.org/10.1017/ S0003975603001322

Halachmi, A. (2002). Performance measurement, accountability, and improved performance. Public Performance and Management Review, 25(4), 370-374. https://doi.org/10. 1080/15309576.2002.11643674

Harzing, A-W., Alakangas, S. (2016). Google Scholar, Scopus and the Web of Science: a longitudinal and crossdisciplinary comparison. Scientometrics, 106(2), pp. 787804. https://doi.org/10.1007/s11192-015-1798-9

Hebson, G., Grimshaw, D., \& Marchington, M. (2003). PPPs and the changing public sector ethos: Case-study evidence from the health and local authority sectors. Work, Employment and Society, 17(3), 481-501. https://doi.org/10. $1177 / 09500170030173005$

Higgins, C.D., Huque, A.S. (2015). Public money and Mickey Mouse: Evaluating performance and accountability in the Hong Kong Disneyland joint venture public-private partnership. Public Management Review, 17(8), 1103-1123. https://doi.org/10.1080/14719037.2014.881533

Hirschman, A.O. (1970). Exit, voice, \& loyalty: Responses to decline in firms, organizations, and states. Cambridge, MA: Harvard University Press.

Hodge, G., \& Greve, C. (2007). Public-private partnerships: An international performance review. Public Admin- 
istration Review, 67(3), 545-558. https://doi.org/10.1111/ j.1540-6210.2007.00736.x

Hodge, G.A., \& Coghill, K. (2007). Accountability in the privatized state. Governance, 20(4), 675-702. https://doi. org/10.1111/j.1468-0491.2007.00377.x

Hodges, R., \& Mellett H. (2012). The U.K. private finance initiative: An accounting retrospective. British Accounting Review, 44(4), 235-247. https://doi.org/10.1016/j.bar.2012. 09.005

Jensen, M., \& Meckling, W. (1976). Theory of the rm: Managerial behaviour, agency costs and ownership structure. Journal of Financial Economics, 3(4), 305-360. https://doi. org/10.1016/0304-405X(76)90026-X

Jos, P.H., \& Tompkins, M.E. (2004). The Accountability paradox in an age of reinvention. Administration and Society, 36(3), 255-81. https://doi.org/10.1177/ 0095399704263479

Joss, S. (2010). Accountable governance, accountable sustainability? A case study of accountability in the governance for sustainability. Environmental Policy and Governance, 20(6), 408-421. https://doi.org/10.1002/eet.559

Ke, Y., Hao, W., Ding, H., Wang, Y. (2017). Factors influencing the private involvement in urban rail public-private partnership projects in China. Construction Economics and Building, 17(1), 90-106. https://doi.org/10.5130/AJCEB.v17i1. 5105

Kort, M., \& Klijn, E-H. (2013). Public-private partnerships in urban regeneration: Democratic legitimacy and its relation with performance and trust. Local Government Studies, 39(1), 89-106. https://doi.org/10.1080/03003930.2012.683864

Levine-Clark, M., \& Gil, E. L. (2008). A comparative citation analysis of Web of Science, Scopus, and Google Scholar. Journal of Business \& Finance Librarianship, 14(1), pp. 32-46. https://doi.org/10.1080/08963560802176348

Mulgan, R. (2003) Holding Power to Account, New York: Palgrave. https://doi.org/10.1057/9781403943835

Murphy, T.J. (2008). The case for public-private partnerships in infrastructure. Canadian Public Administration, 51(1), 99-126. https://doi.org/10.1111/j.1754-7121.2008. 00006.x

Papadopoulos, Y. (2007). Problems of democratic accountability in network and multilevel governance. European Law Journal, 13(4), 469-486. https://doi.org/10.1111/j. 1468-0386.2007.00379.x

Peters, G., \& Pierre, J. (2010). Public-private partnerships and the democratic deficit: Is performance-based legitimacy the answer? In Bexell, M., \& Mörth, U. (Eds.) Democracy and Public-Private Partnerships in Global Governance (pp. 41-54). Basingstoke: Palgrave Macmillan. https://doi.org/10.1057/ 9780230283237/ 3

Powell, W. W. (1990). Neither Market Nor Hierarchy: Network Forms of Organization. In Markets, Hierarchies, and Networks : The Coordination of Social Life (Ed. Grahame Thompson ... et al.). London: Sage.

Reeves, E. (2013). The not so good, the bad and the ugly: Over twelve years of PPP in Ireland. Local Government Studies, 39(3), 375-395. https://doi.org/10.1080/03003930. 2013.781023

Rhodes, R. A. W. (1997). Understanding Governance: Policy Networks, Governance, Reflexivity and Accountability. Maidenhead: Open University Press.

Romzek, B. and Dubnick, M. (1987) Accountability in the Public Sector: Lessons from the Challenger Tragedy. Public Administration Review, 47(3), 227-38. https://doi.org/10. 2307/975901

Ross, S. (1973). The Economic Theory of Agency: The
Principal's Problem. The American Economic Review. 63(2): 134-9.

Sands, V. (2006). The right to know and obligation to provide: Public-private partnerships, public knowledge, public accountability, public disenfranchisement and prison cases. UNSW Law Journal, 29(3), 334-41. Available at http://www.unswlawjournal.unsw.edu.au/wp-content/ uploads/2017/09/29-3-2.pdf [Accessed 25/04/2018]

Savas, E.S. (2000). Privatization and public-private partnerships. New York: Chatham House.

Schedler, A. (1999). 'Conceptualizing Accountability'. In A. Schedler, L. Diamond, \& M. Plattner (Eds.). The SelfRestraining State: Power and Accountability in New Democracies. 13-28. Boulder, London: Lynne Rienner.

Shaoul, J. (2002). A financial appraisal of the London underground public-private partnership. Public Money and Management, 22(2), 53-60. https://doi.org/10.1111/ 1467-9302.00308

Shaoul, J., Stafford, A., \& Stapleton, P. (2012). Accountability and corporate governance of public private partnerships. Critical Perspectives on Accounting, 23(3), 213-229. https://doi.org/10.1016/j.cpa.2011.12.006

Siemiatycki, M. (2007). What's the secret? Confidentiality in planning infrastructure using public/private partnerships. Journal of the American Planning Association, 73(4), 388-403. https://doi.org/10.1080/01944360708978520

Steets, J. (2010). Accountability in public policy partnerships. New York: Palgrave Macmillan. https://doi.org/10. 26530/OAPEN/_392745

Toms, S., Beck, M., Asenova, D. (2011). Accounting, regulation and profitability: The case of PFI hospital refinancing. Critical Perspectives on Accounting, 22(7), 668-681. https://doi.org/10.1016/j.cpa.2011.01.010

Tranfield, D., Denyer, D., \& Smart, P. (2003). Towards a methodology for developing evidence-informed management knowledge by means of systematic review. British Journal of Management, 14, 207-222. https://doi.org/10. 1111/1467-8551.00375

Van Ham, H., \& Koppenjan, J.F.M. (2001) Building publicprivate partnerships: Assessing and managing risks in port development. Public Management Review, 3(4), 593-616. https://doi.org/10.1080/14616670110070622

Velotti, L., Botti, A., \& Vesci, M. (2012). Public-private partnerships and network governance: What are the challenges? Public Performance and Management Review, 36(2), 340-365. https://doi.org/10.2753/PMR1530-9576360209

Voorberg, W.H., Bekkers, V.J.J.M., \& Tummers, L.G. (2015). A Systematic review of co-creation and co-production: Embarking on the social innovation journey. Public Management Review, 17(9), 1333-1357. https://doi.org/10.1080/ 14719037.2014.930505

Warner, M.E. (2010). The future of local government: Twenty-first-century challenges. Public Administration Review, 70(1), 145-147. https://doi.org/10.1111/j. 1540-6210.2010.02257.x

Weihe, G. (2006), April. Public-private partnerships: addressing a nebulous concept. Paper presented at the 10th International Research Symposium on Public Management. Glasgow, Scotland. Avilable at https://openarchive.cbs.dk/bitstream/handle/10398/ 7348/ppp/_approaches/_guri/_16.pdf?sequence=1 [Accessed 04.07.2018]

West, K. (2005). From bilateral to trilateral governance in local government contracting in France. Public Administration, 83(2), 473-492. https://doi.org/10.1111/j. 
0033-3298.2005.00458.x

Willems, T. (2014). Democratic accountability in publicprivate partnerships: the curious case of Flemish school infrastructure. Public Administration, 92(2), 340-358. https: //doi.org/10.1111/padm.12064

Willems, T., \& Van Dooren, W. (2011). Lost in diffusion? How collaborative arrangements lead to an accountability paradox. International Review of Administrative Sciences, 77(3), 505-530. https://doi.org/10.1177/ 0020852311408648

Willems, T., \& Van Dooren, W. (2012). Coming to Terms with Accountability. Public Management Review, 14(7), 1-26. https://doi.org/10.1080/14719037.2012.662446 